RMD Open

Rheumatic \&

Musculoskeletal Diseases

To cite: Punzi L, Favero M, Frallonardo $\mathrm{P}$, et al. Time to redefine erosive osteoarthritis. RMD Open 2015;1:e000105. doi:10.1136/rmdopen-2015000105

- Prepublication history for this paper is available online. To view these files please visit the journal online (http://dx.doi.org/10.1136/ rmdopen-2015-000105).

Received 23 March 2015 Revised 24 August 2015 Accepted 31 August 2015

CrossMark

${ }^{1}$ Rheumatology Unit, Department of Medicine DIMED, University of Padova, Padova, Italy

${ }^{2}$ Laboratory of

Immunorheumatology and

Tissue Regeneration/

RAMSES, Rizzoli Orthopedic Research Institute, Bologna, Italy

Correspondence to Professor Leonardo Punzi; punzireu@unipd.it

\title{
Time to redefine erosive osteoarthritis
}

\author{
Leonardo Punzi, ${ }^{1}$ Marta Favero, ${ }^{1,2}$ Paola Frallonardo, ${ }^{1}$ Roberta Ramonda ${ }^{1}$
}

Osteoarthritis (OA), a disease that mainly targets cartilage, also affects ligaments, the subchondral bone and synovium, and, $j$ according to recent definitions, it is a disease of the joint as an organ. ${ }^{1}$ Its most characteristic radiographic features are joint space narrowing, bone sclerosis and osteophytes; ${ }^{2}$ bone erosions, and in particular subchondral bone erosions, have also been found in some patients. ${ }^{3}$ Bone erosions that classically affect the interphalangeal (IP) joints identify a disease subset called erosive osteoarthritis (OA) ${ }^{4}$ The particular localisation of erosive $\mathrm{OA}$ is considered so characteristic of the disease that the term has been used, since it was first described by Peter $e t a l,{ }^{5}$ almost interchangeably with erosive hand OA. A growing body of evidence, however, suggests that it is time to re-evaluate the definition, since the term erosive OA can be appropriately applied to other OA localisations including at the thumb base (TB) ${ }^{6}$ and facet joints. ${ }^{7}$ These different disease subsets share not only the same classic radiographic features, such as subchondral bone erosions, but also the severity of the disease's clinical expression.

Unlike the classical clinical features noted in the large majority of patients with hand $\mathrm{OA}$, erosive $\mathrm{OA}$ is characterised by an abrupt onset, swelling and erythema, as well as functional and at times symmetric limitation of several joints. ${ }^{8}$

As these aspects seem quite similar to those found in inflammatory joint diseases, the term inflammatory OA, which has been proposed by some authors, does indeed seem justified. ${ }^{9}$ New sensitive imaging techniques have demonstrated that the same radiological and clinical manifestations can also be found in $\mathrm{TB}$ and facet joint OA. ${ }^{6} 7$

According to a population-based observational study carried out in North Staffordshire, focusing on two cohorts and examining 1076 participants with hand symptoms $\geq 1$ day during the previous month, ${ }^{10}$ it did not seem appropriate to include the TB joints (first carpometacarpal (CMC) and scaphoid-trapezoid (ST) joints) within the clinical spectrum of erosive hand $\mathrm{OA}$. The prevalence of the erosive form in CMC joints was $2.2 \%$, but only $0.5 \%$ of the patients had erosive disease simultaneously affecting the IP joints and first CMC joints. Only a small number of patients thus had erosive OA both at the IP joints and first CMC joints, while the rest of the participants had erosive $\mathrm{OA}$ exclusively at the IP joints or first CMC joints. According to that study's data, men are more frequently affected by erosive TB OA than women, ${ }^{10}$ which was an unexpected finding since erosive IP joint OA mostly affects females. In view of the findings outlined here, it would seem reasonable to consider erosive TB OA as a separate entity from erosive IP OA. In view of Kwok et $a l \mathrm{~s}^{10}$ data and the different gender prevalences that have been found, it also seems appropriate to consider erosive IP joint OA and erosive TB OA as two different subsets of erosive $\mathrm{OA}$ of the hand.

But it is also important to remember that the term erosive can also be applied to sites other than the hand. Two recent studies published, respectively, by Gellhorn et $a l^{11}$ and Suri et $a l^{12}{ }^{12}$ focused, in fact, on severe facet joint OA.

Facet joint $\mathrm{OA}$ is a frequent cause of back and neck pain. The radiological features of apophyseal joint $\mathrm{OA}$ include narrowing of the facet joint space, subarticular bone erosions, subchondral cysts, osteophyte formation and hypertrophy of the articular process. Facet joint $\mathrm{OA}$ is not distributed equally throughout the spine: the lower part of the lumbar region (L4-L5 and L5-S1) and the mid-cervical region (C3-C5) are more frequently affected. ${ }^{13}$

The clinical syndrome of painful facet joints usually includes localised neck or back pain with some degree of radiation into the upper or lower limbs. Facet joint OA has been associated with degenerative disease. Structural changes of the facet joints can be caused by increased loading, which leads to degeneration of the disc or disc-space narrowing. ${ }^{14} \mathrm{Up}$ to $70 \%$ of the axial load can be borne by the facet joints in the event of severe disc-space narrowing. ${ }^{15} \mathrm{OA}$ of the facet joints should always be taken into consideration when a differential diagnosis of low back and cervical pain is being made, especially in 
older adults. If, moreover, erosions are found when the facet joints undergo imaging procedures, rheumatoid arthritis, spondyloarthritis and gout, as well as erosive facet joint $\mathrm{OA}$, should all be taken into consideration.

To conclude, erosions, which tend to be more frequent than expected in $\mathrm{OA}$ and which certainly warrant further analysis, are often associated with severe clinical presentation and evolution. It is probably time to redefine erosive $\mathrm{OA}$, which should be distinguished into three main subtypes: erosive hand OA of IP joints, erosive hand OA of $\mathrm{TB}$ joints and erosive $\mathrm{OA}$ of the facet joints.

Competing interests None declared.

Provenance and peer review Commissioned; externally peer reviewed.

Data sharing statement No additional data are available.

Open Access This is an Open Access article distributed in accordance with the Creative Commons Attribution Non Commercial (CC BY-NC 4.0) license, which permits others to distribute, remix, adapt, build upon this work noncommercially, and license their derivative works on different terms, provided the original work is properly cited and the use is non-commercial. See: http:// creativecommons.org/licenses/by-nc/4.0/

\section{REFERENCES}

1. Loeser RF, Goldring SR, Scanzello CR, et al. Osteoarthritis: a disease of the joint as an organ. Arthritis Rheum 2012;64:1697-707.

2. Zhang W, Doherty M, Leeb BF, et al. EULAR evidence-based recommendations for the diagnosis of hand osteoarthritis: report of a task force of ESCISIT. Ann Rheum Dis 2009;68:8-17.
3. Altman RD, Gold GE. Atlas of individual radiographic features in osteoarthritis, revised. Osteoarthritis Cartilage 2007;15(Suppl A): A1-56.

4. Punzi L, Ramonda R, Sfriso P. Erosive osteoarthritis. Best Pract Res Clin Rheumatol 2004;18:739-58.

5. Peter JB, Pearson CM, Marmor L. Erosive osteoarthritis of the hands. Arthritis Rheum 1966;9:365-88.

6. Saltzherr MS, van Neck JW, Muradin GS, et al. Computed tomography for the detection of thumb base osteoarthritis: comparison with digital radiography. Skeletal Radiol 2013;42:715-21.

7. Weishaupt D, Zanetti M, Boos N, et al. MR imaging and CT in osteoarthritis of the lumbar facet joints. Skeletal Radiol 1999;28:215-19.

8. Ramonda R, Frallonardo P, Musacchio E, et al. Joint and bone assessment in hand osteoarthritis. Clin Rheumatol 2014;33: $11-19$.

9. Punzi L, Frigato M, Frallonardo $\mathrm{P}$, et al. Inflammatory osteoarthritis of the hand. Best Pract Res Clin Rheumatol 2010;24:301-12.

10. Kwok WY, Kloppenburg M, Marshall M, et al. The prevalence of erosive osteoarthritis in carpometacarpal joints and its clinical burden in symptomatic community-dwelling adults. Osteoarthritis Cartilage 2014;22:756-63.

11. Gellhorn AC, Katz JN, Suri P. Osteoarthritis of the spine: the facet joints. Nat Rev Rheumatol 2013;9:216-24.

12. Suri P, Hunter DJ, Rainville J, et al. Presence and extent of severe facet joint osteoarthritis are associated with back pain in older adults. Osteoarthritis Cartilage 2013;21:1199-206.

13. Kalichman L, Li L, Kim DH, et al. Facet joint osteoarthritis and low back pain in the community-based population. Spine (Phila Pa 1976) 2008:33:2560-5.

14. Goode AP, Carey TS, Jordan JM. Low back pain and lumbar spine osteoarthritis: how are they related? Curr Rheumatol Rep 2013;15:305.

15. Adams MA, Hutton WC. The mechanical function of the lumbar apophyseal joints. Spine (Phila Pa 1976) 1983;8: 327-30. 